\title{
Resistin-like molecule- $\beta$ is a human airway remodelling mediator
}

\author{
C. Fang*, Q. Meng*, H. Wu*, G. Eid*, G. Zhang* ${ }^{*}$ X. Zhang*, S. Yang*, K. Huang", \\ T.H. Lee*, C.J. Corrigan* and S. Ying*
}

ABSTRACT: Though implicated in vascular remodelling, a role for the resistin-like molecule (RELM)- $\beta$ in human airway remodelling remains unexplored. We hypothesised that RELM- $\beta$ expression is increased in the airways of asthmatics and regulates airways epithelial cell function.

Expression of RELM- $\beta$ in the bronchial mucosa and its concentrations in bronchoalveolar lavage (BAL) fluid from asthmatics and controls were measured by immunohistochemistry and ELISA, respectively. Proliferation assays, Western blotting, ELISA and real-time PCR were employed to detect effects of RELM- $\beta$ on airways epithelial cells.

RELM- $\beta$ expression was increased in the bronchial mucosa and BAL fluid of asthmatics compared with controls. In the asthmatics, the numbers of mucosal RELM- $\beta+$ cells correlated inversely with forced expiratory volume in $1 \mathrm{~s}(r=-0.531, p=0.016)$, while the numbers of epithelial RELM- $\beta+$ cells correlated positively with those of mucin (MUC)5AC+ cells. In vitro, interleukin-13 enhanced RELM- $\beta$ expression by primary human airways epithelial cells, while RELM- $\beta$ itself acted on these cells to induce proliferation, expression of MUC5AC, extracellular signal-regulated kinase (ERK)/mitogen-activated protein kinase (MAPK)-phosphatidylinositol 3kinase (PI3K)/Akt phosphorylation and elevated expression of transforming growth factor- $\beta 2$, epidermal growth factor and vascular endothelial growth factor.

RELM- $\beta$ has the potential to contribute to airway remodelling in diseases such as asthma by acting on epithelial cells to increase proliferation, mucin and growth factor production, at least partly via ERK/MAPK-PI3K/Akt signalling pathways.

KEYWORDS: Airways epithelial cells, asthma, mucus, remodelling, resistin-like molecule- $\beta$

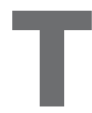
he protein known as resistin-like molecule (RELM)- $\beta$ or found in inflammatory zone (FIZZ)-2 belongs to the RELM/FIZZ family of cysteine-rich secretory proteins that share homology with resistin. So far, four members of this family have been identified: RELM- $\alpha$ (FIZZ-1), RELM- $\beta$ (FIZZ-2), resistin (FIZZ-3) and RELM- $\gamma[1$, 2]. The proteins are 105-114 amino acids in length and comprised of three domains: an N-terminal signal sequence; a variable middle portion; and a highly conserved C-terminal signature sequence that constitutes nearly half of the molecule [3]. It is speculated that the highly conserved signature region contributes to binding to a related family of receptors that is yet to be discovered. Studies in animals suggest that members of the RELM/ FIZZ family have important pro-inflammatory and remodelling roles. For example, RELM- $\alpha /$ FIZZ-1 was first discovered in the "inflammatory zone" of mice with allergic pulmonary inflammation [4] and has also been described as a hypoxia-inducible mitogenic factor implicated in hypoxia-associated vascular remodelling [5]. RELM- $\alpha /$ FIZZ-1 has never been observed in humans, in which species the gene does not appear to exist [6]. Conversely, RELM- $\beta$ /FIZZ-2 is both expressed and highly conserved in mice and humans, especially in the C-terminus, which most resembles resistin [7]. It has been implicated in the mechanism of airway remodelling in a murine model of asthma [7] and is also clearly secreted into the lumen of the gut in mice [8], suggesting that it may function as a local mediator at a variety of epithelial surfaces. In humans, it has been described as a product of epithelial, fibroblast and smooth muscle cells at sites of vascular remodelling [9].

In this study, we wished to investigate its possible role as a remodelling mediator in asthmatic airways. We hypothesised that: RELM- $\beta /$ FIZZ-2 is overexpressed in the asthmatic bronchial mucosa and lumen; and that it is induced by interleukin (IL)-13, a key asthma remodelling mediator, in epithelial cells, and itself acts on these same cells to induce changes understood to be relevant to remodelling, including proliferation, mucous hyperplasia and production
AFFILIATIONS

${ }^{*} \mathrm{MRC}$ and Asthma UK Centre for Allergic Mechanisms of Asthma, Dept of Asthma, Allergy and Respiratory Science, King's College London, London, UK.

\#Dept of Central Research, The Third Clinical College, Jilin University, Changchun, and

-Division of Pulmonary and Critical Care Medicine, Beijing Chao-Yang Hospital, Capital Medical University, and Beijing Institute of Respiratory Medicine, Beijing, China.

CORRESPONDENCE

S. Ying

Dept of Asthma, Allergy and

Respiratory Science

5th Floor

Tower Wing

Guy's Hospital

King's College London

London

SE1 9RT

UK

E-mail: ying.sun@kcl.ac.uk

Received:

June 232011

Accepted after revision:

July 182011

First published online:

Aug 042011 
of a range of further remodelling mediators including transforming growth factor (TGF)- $\beta$, epithelial growth factor (EGF) and vascular endothelial growth factor (VEGF).

\section{METHODS}

\section{Subjects and fibreoptic bronchoscopy}

The study was approved by the Ethics Committee of Guy's Hospital, part of King's College London School of Medicine (London, UK). Each participant provided written, informed consent. Asthmatics had a clear history of relevant symptoms, documented reversible airway obstruction $(\geqslant 12 \%$ improvement in forced expiratory volume in $1 \mathrm{~s}$ (FEV1) either spontaneously or after administration of inhaled $\beta_{2}$-agonist) and/or histamine provocative concentration causing a $20 \%$ fall in FEV $1<8 \mathrm{mg} \cdot \mathrm{mL}^{-1}$ measured within 2 weeks prior to biopsy. None had ever smoked and there was no history of other respiratory disease. Normal control subjects were healthy, lifelong nonsmoking volunteers who had no history of lung disease. All subjects were clinically free of respiratory infection and systemic glucocorticoid therapy for $\geqslant 1$ month prior to the study. Atopy was defined as a positive skin-prick test (wheal at $15 \mathrm{~min}>3 \mathrm{~mm}$ in diameter in the presence of positive histamine and negative diluent controls) to one or more extracts of common local aeroallergens. By these criteria, 10 out of 20 control subjects and 15 out of 20 asthmatic subjects were atopic. Endobronchial biopsy specimens and bronchoalveolar lavage (BAL) fluid were obtained at fibreoptic bronchoscopy and processed as previously described [10, 11].

\section{Immunohistochemistry and image analysis}

Immunostaining for RELM- $\beta$ was carried out on sections of the bronchial biopsies according to well-established protocols [10, 11]. Briefly, $6-\mu \mathrm{m}$ sections were incubated in $1 \% \mathrm{H}_{2} \mathrm{O}_{2}$ in $3 \mathrm{M}$ $\mathrm{NaN}_{3}$ in PBS for $40 \mathrm{~min}$ at room temperature to block endogenous peroxidase activity. After washing, sections were incubated with primary antibody (rabbit anti-human RELM- $\beta$, 1/50; Abcam Plc, Cambridge, UK) in 5\% human serum/PBS for $2 \mathrm{~h}$ at room temperature. Following washes, the sections were incubated with goat anti-rabbit immunoglobulin (Ig)G (1/100; Dako Ltd, Cambridge, UK) for $30 \mathrm{~min}$, washed and then incubated with horseradish peroxidase-conjugated rabbit antigoat (1/100; Dako) for $30 \mathrm{~min}$ (Dako). RELM- $\beta$ immunoreactivity was visualised using 3,3'-diaminobenzidine (DAB) (SigmaAldrich, Gillingham, UK). As a negative control, the primary antibody was pre-absorbed with human recombinant human RELM- $\beta$ and this abolished its binding to tissue sections. The lengths of epithelium, areas of sections and numbers of RELM- $\beta$ immunoreactive cells in the bronchial mucosa were determined objectively in a blinded fashion on an Olympus BX40 microscope connected with a Zeiss Vision KS300 imaging system (Carl Zeiss, Oberkochen, Germany) [11].

Mucin protein immunoreactivity was detected with a monoclonal antibody to human mucin (MUC)5AC (mouse antiMUC5AC, 1/50; AbD Serotec, Kidlington, UK). The primary antibody was detected by incubation with a donkey antimouse IgG (1/50; Dako) and mouse peroxidase-antiperoxidase complex (1/50; Dako). Positive signals were detected as above. MUC5AC immunoreactive cells were counted and results were expressed as the numbers of positive cells per $\mathrm{mm}$ length of basement membrane.
To characterise the phenotypes of cells expressing RELM- $\beta$, sequential immunohistochemical staining was preformed as previously described [10, 11]. Murine monoclonal antibodies directed against cellular phenotypic markers were purchased from Dako (macrophage CD68, 1/50; endothelial cells CD31, $1 / 30$; mast cell tryptase, $1 / 50$; neutrophil elastase, 1/50), Becton Dickinson (Oxford, UK) (T-cell CD3, 1/10), Abcam plc (human fibroblasts 5B5, 1/50) and AbD Serotec (MUC5AC, 1/50). A monoclonal antibody against major basic protein was a kind gift from A.B. Kay (Faculty of Medicine, Imperial College, London, UK) [10, 11].

\section{Measurement of RELM- $\beta$ concentrations in BAL fluid and supernatants from cultured epithelial cells}

As a result of the large dilution effect of the instilled fluid and the expected low concentration of RELM- $\beta$, BAL fluid samples were concentrated 30-fold using Amicon Ultra-15 filters (Millipore Corporation, Billerica, MA, USA) with a molecular weight cut-off of $5 \mathrm{kDa}$, according to the manufacturer's recommendations as previously described [10]. Samples were adjusted, where necessary, so that analyte concentrations fell within the linear range of the standard curves. The data were normalised to the total protein content of the fluid as determined by the bicinchoninic acid protein assay (Pierce, Rockford, IL, USA) according to the manufacturer's instructions. The concentrations of human RELM- $\beta$ in concentrated BAL fluid and supernatants from cultured airways epithelial cells (see later) were measured using a commercial ELISA kit according to the manufacturer's instructions (Antigenix America Inc., Huntington Station, NY, USA). The limit of detection was $75 \mathrm{pg} \cdot \mathrm{mL}^{-1}$.

\section{Epithelial cell culture}

Primary human bronchial epithelial cells (HBECs) were obtained from three of the control, nonsmoking adult donors by cytological brushing of the large airways at bronchoscopy. Recovered epithelial cells were plated onto bovine collagen I-coated six-well culture plates and grown to monolayers at $37^{\circ} \mathrm{C}$ in a $5 \% \mathrm{CO}_{2}$-humidified atmosphere as previously described [12]. All experiments were performed on cells at $\sim 80 \%$ confluence and following three to six passages.

\section{Proliferation assay}

Proliferation was measured by (4,5-dimethylthiazol-2-yl)-2,5diphenyl tetrazolium bromide (MTT) incorporation according to the manufacturer's instructions (Sigma-Aldrich). Prior to stimulation, HBECs were plated at 10,000 cells in $100 \mu \mathrm{L}$ BEGM, starved in serum/growth factor-free medium for $24 \mathrm{~h}$ then treated with fresh BEGM containing recombinant human RELM- $\beta$ (Abcam; 0, 1, 10 and $100 \mathrm{ng} \cdot \mathrm{mL}^{-1}$ ) or IL-13 $\left(10 \mathrm{ng} \cdot \mathrm{mL}^{-1}\right.$; R\&D Systems, Oxford, UK), with or without U0126 (mitogenactivated protein/extracellular signal-regulated kinase 1 and 2 (MEK1 and MEK2) inhibitor, $5 \mu \mathrm{M}$; Calbiochem Corp., La Jolla, CA, USA) and Bay11-7082 (nuclear factor (NF)- $\kappa \mathrm{B}$ inhibitor, $2.5 \mu \mathrm{M}$; Cayman Chemicals, Ann Arbor, MI, USA). After $48 \mathrm{~h}$ of incubation, the MTT assay was used to measure cellular proliferation as previously described [13]. In each experiment, at least three wells were used for each condition.

\section{RNA extraction and real-time PCR}

After 8 and $24 \mathrm{~h}$ of stimulation, total cellular RNA was extracted from cultured HBECs using the RNeasy Mini kit 


\begin{tabular}{|c|c|c|}
\hline \multirow{2}{*}{$\begin{array}{l}\text { TABLE } 1 \\
\text { Gene }\end{array}$} & \multicolumn{2}{|c|}{$\begin{array}{l}\text { Primers used for real-time, quantitative real-time } \\
\text { PCR }\end{array}$} \\
\hline & Forward primer & Reverse primer \\
\hline \multirow[t]{2}{*}{ RELM- $\beta$} & 5'-CCC TTC TCC & $5^{\prime}-\mathrm{CCA}$ CGA ACC \\
\hline & AGC TGA TCA AC-3' & ACA GCC ATA G-3' \\
\hline \multirow[t]{2}{*}{ TGF- $\beta 1$} & 5'-CCT GCA AGA CTA & 5'-ACA CGG GTT CAG \\
\hline & TCG ACA TGG AGC-3' & GTA CCG CTT CTC-3' \\
\hline \multirow[t]{2}{*}{ TGF- $\beta 2$} & 5'-ATC CCG CCC ACT & 5"-CAT CCA AAG \\
\hline & TTC TAC AGA C-3' & CAC GC TTC TTC C-3' \\
\hline \multirow[t]{2}{*}{ MUC5AC } & 5'-TGA TCA TCC & 5'-CGA GCT CAG \\
\hline & AGC AGC AGG GT-3' & AGG ACA TAT GGG-3' \\
\hline \multirow[t]{2}{*}{ EGF } & 5'-ACT GTG TTG & 5'-TCA GGA GGA \\
\hline & TTG GCT ACA TCG G-3' & GCA GCA TGA CA-3' \\
\hline \multirow[t]{2}{*}{ VEGF } & 5'-TAC CTC CAC & 5'-GAT GAT TCT \\
\hline & CAT GCC AAG TG-3' & GCC СТC СТC СТT-3' \\
\hline \multirow[t]{2}{*}{ 18sRNA } & 5'-TGA CTC AAC ACG & 5"-GGA CAT CTA AGG \\
\hline & GGA AAC CTC AC-3' & GCA TCA CAG ACC-3' \\
\hline
\end{tabular}

RELM: resistin-like molecule; TGF: transforming growth factor; MUC5AC: mucin 5AC; EGF: epidermal growth factor; VEGF: vascular endothelial growth factor.

(QIAGEN, Crawley, UK). $2 \mu \mathrm{g}$ RNA were DNase treated followed by reverse transcription according to the kit instructions. Quantitative real-time PCR was performed on a 7500 Real-Time PCR System (Applied Biosystems, Warrington, UK) [13]. Gene expression was normalised to $18 \mathrm{~S}$ ribosomal RNA (rRNA) (used as endogenous loading control) and presented as fold increase relative to medium. Real-time PCR primers for human RELM- $\beta$, TGF- $\beta 1$ and 2 , EGF, VEGF, MUC5AC and $18 S$ RNA are summarised in table 1 .

\section{Western blotting for total and phosphorylated (p42/44) extracellular signal-regulated kinase-1/2, phosphatidylinositol 3-kinase and Akt}

After incubation with or without RELM- $\beta$, the cultured human airways epithelial cells were washed with ice-cold PBS and then lysed in $50 \mu \mathrm{L}$ lysis buffer ( $25 \mathrm{mM}$ 4-(2-hydroxyethyl)-1piperazineethanesulfonic acid, $1.5 \%$ Triton $\mathrm{X}-100,0.1 \%$ sodium dodecyl sulfate, $0.5 \mathrm{M} \mathrm{NaCl}, 5 \mathrm{mM}$ EDTA, $0.1 \mathrm{mM}$ sodium deoxycholate) (Sigma-Aldrich) containing a protease inhibitor cocktail (Roche, Welwyn, UK) and sodium orthovanadate (10 mM; Sigma-Aldrich). Western blotting was performed to detect phosphorylation of extracellular signal-regulated kinase (ERK)1/2, phosphatidylinositol 3-kinase (PI3K) and Akt as previously described $[13,14]$.

\section{ELISA for TGF- $\beta 1$, TGF- $\beta 2$, EGF and VEGF}

Primary cultured epithelial cells were serum starved for $24 \mathrm{~h}$ and then stimulated with RELM- $\beta$ for 24 and $48 \mathrm{~h}$. ELISA kits were employed to measure TGF- $\beta 1$, TGF- $\beta 2$, EGF and VEGF according to the manufacturer's instructions (R\&D Systems). Limits of detection for these ELISA analyses were 15.4, 15.4, 3.9 and $16 \mathrm{pg} \cdot \mathrm{mL}^{-1}$, respectively.

\section{Effect of RELM- $\beta$ on MUC5AC expression by HBECs}

MUC5AC mRNA and protein were measured by real-time PCR and ELISA in HBECs cultured using an air-liquid interface culture system [15]. Briefly, cells were seeded on type I collagencoated semi-permeable Trans well membrane (Corning Inc., Corning, NY, USA) inserts at a density of $10^{5}$ cells per $24-\mathrm{mm}$ well in a 1/1 (volume/volume) mixture of bronchial epithelial cell growth medium (BGEM) and Dulbecco's modified Eagle's medium (Invitrogen, Paisley, UK). HBECs were grown completely submerged for 1 week. The apical medium was removed on day 8 and cells were grown at an air-liquid interface with culture media in the basal compartment changed daily for 3 weeks. After the cells had reached confluence, they were serum-starved for $24 \mathrm{~h}$ before adding recombinant RELM- $\beta$ with or without the ERK inhibitor U0126. After $24 \mathrm{~h}$, cell culture supernatants and lysates were collected to measure MUC5AC expression. MUC5AC protein was measured by ELISA as previously described [15]. The amounts of MUC5AC in culture supernatants were expressed as $\mu \mathrm{g}$ of mucin per mg of total protein.

\section{Statistical analysis}

Data were analysed using a statistical package (Minitab Release 7; Minitab Inc., State College, PA, USA). For the bronchial biopsies and BAL, the Mann-Whitney U-test was used for between group comparisons. For PCR, proliferation, ELISA and other assays, the data were analysed by paired t-test. Correlation coefficients were obtained by Spearman's rank-order method with correction. For all tests, $\mathrm{p}<0.05$ was considered significant.

\section{RESULTS}

\section{Study participant characteristics}

In total, 40 subjects ( 20 asthmatics, 10 of whom were female, aged $27-50 \mathrm{yrs}$ and 20 controls, 12 of whom were female, aged 20-38 yrs) participated in the study. The baseline FEV1 was significantly lower in the asthmatics (median 81.5 (range 42.0 $116.0) \%$ predicted) than in the control subjects (101.5 (81.0-122.0) $\%$ pred; $\mathrm{p}<0.0001)$. The median total serum IgE concentration in asthmatics (84.8 (17.6-789.3) IU $\left.\cdot \mathrm{mL}^{-1}\right)$ was significantly higher than that of the controls (46.6. (15.9-241.6) IU $\left.\cdot \mathrm{mL}^{-1} ; \mathrm{p}=0.0275\right)$.

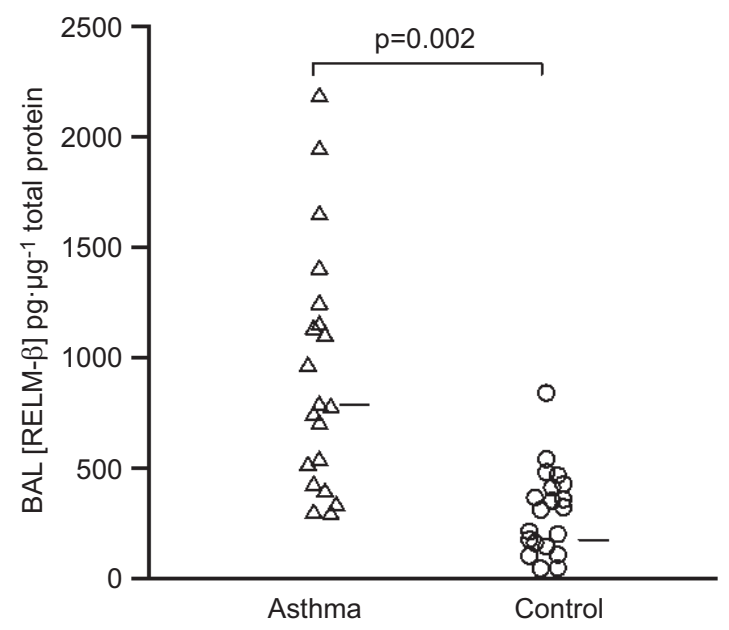

FIGURE 1. Concentrations of resistin-like molecule (RELM)- $\beta$ in bronchoalveolar lavage (BAL) fluid from asthmatic $(n=20)$ and control subjects $(n=20)$ Analysed using Mann-Whitney U-test. Bars show medians. 

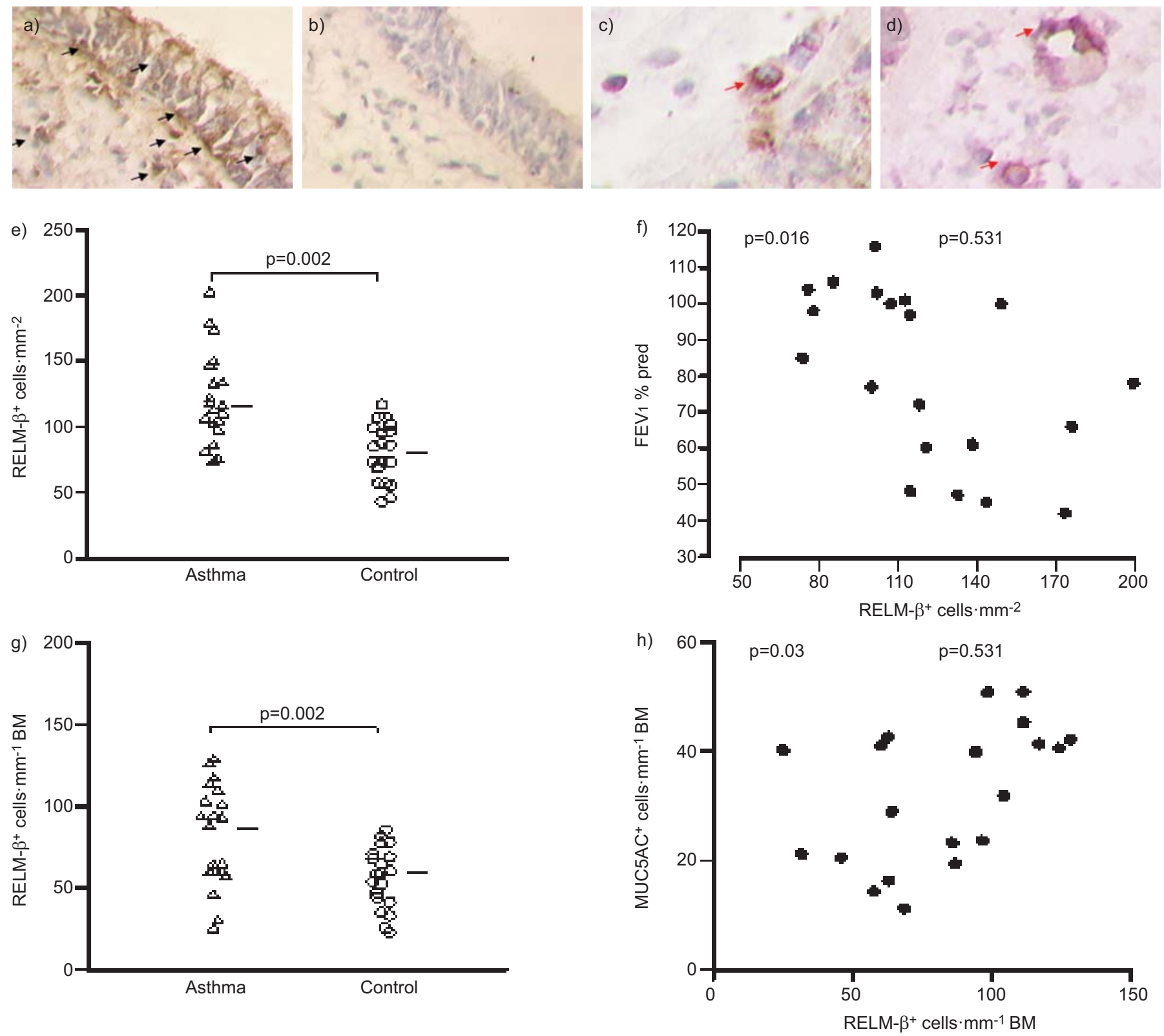

FIGURE 2. Resistin-like molecule (RELM)- $\beta$ immunoreactivity in sections of bronchial biopsies. a) RELM- $\beta+$ cells (arrows) in sections of asthmatic bronchial biopsy; b) negative control (absorbed antibody); c) CD68+ macrophage; and d) CD31+ endothelial cells with RELM- $\beta$ immunoreactivity (red arrows). RELM- $\beta+$ cells within e) the entire bronchial mucosa including the epithelium (results expressed as positive cells $\mathrm{mm}^{-2}$ of biopsy) and $\mathrm{g}$ ) the epithelium alone (results expressed as positive cells $\mathrm{mm}^{-1}$ length basement membrane (BM)). f) Correlation between total numbers of RELM- $\beta+$ cells in entire biopsies and forced expiratory volume in $1 \mathrm{~s}$ (FEV1) \% predicted (\% pred) in asthmatics. h) Correlation between numbers of epithelial RELM- $\beta+$ and mucin (MUC)5AC+ cells in asthmatics. Mann-Whitney U-test and Spearman's rank correlation. $\mathrm{n}=20$ per group. Bars show medians.

\section{Increased expression of RELM- $\beta$ in BAL and bronchial mucosa}

The median concentration of RELM- $\beta$ relative to total protein was significantly higher in BAL from asthmatic subjects compared with control subjects (fig. 1) $(\mathrm{p}=0.002)$. Immunohistochemical analysis of sections of the bronchial biopsies showed RELM- $\beta$ immunoreactivity located in the epithelium and the submucosa (fig. $2 \mathrm{a}-\mathrm{d}$ ). The median number of RELM- $\beta$ immunoreactive cells in the entire sections and in the epithelium alone was significantly increased in the asthmatics compared with the controls (fig. 2e and $g ; p=0.0002$ and 0.007 , respectively). In the asthmatics, the total numbers of RELM- $\beta$ immunoreactive cells correlated inversely with FEV1 (fig. 2f) $(r=-0.531, p=0.016)$, while the numbers of epithelial RELM- $\beta$ and MUC5AC immunoreactive cells correlated positively (fig. $2 \mathrm{~h})(\mathrm{r}=0.531, \mathrm{p}=0.03)$. Double staining showed that $<30 \%$ (mean \pm SD $25.1 \pm 4.2 \%$ ) of MUC5AC+ epithelial cells also expressed RELM- $\beta$. In the submucosa, RELM- $\beta$ immunoreactive cells comprised mainly of macrophages $(36.4 \pm 4.9 \%)$, endothelial cells $(31.7 \pm 3.2 \%)$ and fibroblast-like cells $(19.9 \pm 2.5 \%)$. In contrast, only small percentages of the total 


\begin{tabular}{|c|c|c|c|}
\hline \multirow{2}{*}{$\begin{array}{l}\text { TABLE } 2 \\
\text { Cell marker }\end{array}$} & \multicolumn{3}{|c|}{$\begin{array}{l}\text { Cellular sources of resistin-like molecule } \\
\text { (RELM)- } \beta \text { in the bronchial submucosa }\end{array}$} \\
\hline & & RELM- $\beta$ localised ${ }^{\#} \%$ & Cells expressing RELM- $\beta^{\dagger} \%$ \\
\hline \multicolumn{2}{|c|}{ CD68 (macrophage) } & $36.4 \pm 4.9$ & $56.3 \pm 5.4$ \\
\hline \multicolumn{2}{|c|}{ CD31 (endothelial cell) } & $31.7 \pm 3.2$ & $47.8 \pm 3.9$ \\
\hline \multicolumn{2}{|c|}{ 5B5 (fibroblast) } & $19.9 \pm 2.5$ & $50.1 \pm 4.5$ \\
\hline \multicolumn{2}{|c|}{ Tryptase (mast cell) } & $3.9 \pm 1.4$ & $12.5 \pm 4.1$ \\
\hline \multicolumn{2}{|c|}{ Elastase (neutrophil) } & $3.1 \pm 2.2$ & $10.8 \pm 3.7$ \\
\hline \multicolumn{2}{|c|}{ CD3 (T-cell) } & $2.6 \pm 1.2$ & $6.7 \pm 2.8$ \\
\hline \multicolumn{2}{|c|}{ MBP (eosinophil) } & $2.1 \pm 2.1$ & $5.9 \pm 2.2$ \\
\hline
\end{tabular}

Data are presented as mean \pm SEM. MBP: major basic protein. ${ }^{\#}$ : percentages of total RELM- $\beta+$ cells accounting for the stated phenotypes; $"$ : percentages of total cells of each phenotype expressing RELM- $\beta$ immunoreactivity.

RELM- $\beta$ immunoreactive cells were accounted for by other inflammatory cells (mast cells, $3.9 \pm 1.4 \%$; neutrophils, $3.1 \pm 2.2 \%$; T-cells, $2.6 \pm 1.2 \%$; and eosinophils, $2.1 \pm 2.1 \%$ ). The results are summarised in table 2 .

\section{HBECs express RELM- $\beta$, which increases their proliferation} Cultured HBECs spontaneously expressed RELM- $\beta$ mRNA and secreted the corresponding protein. Both were significantly increased by IL-13 (fig. 3a and b). RELM- $\beta$ increased proliferation of HBECs (fig. 3c) in a concentration-dependent fashion. In contradistinction to IL-13, RELM- $\beta$-induced proliferation of HBECs was completely abolished by the ERK inhibitor U0126, but not the NF- $\kappa$ B inhibitor Bay11-7082 (fig. 3c).

\section{RELM- $\beta$ increases expression of mucin, TGF- $\beta 2, E G F$ and VEGF, but not TGF- $\beta 1$, by HBECs}

RELM- $\beta$ increased expression of mucin by cultured HBECs at the level of both MUC5AC mRNA and secreted mucin protein. Again, the ERK inhibitor U0126 significantly attenuated MUC5AC expression (fig. $4 \mathrm{a}$ and b). RELM- $\beta$ also induced HBEC expression, at the mRNA and protein levels, of TGF- $\beta 2$ (fig. $4 \mathrm{c}$ and $\mathrm{d}$ ) in a concentration-dependent manner. Additionally, RELM- $\beta$ induced expression and secretion of EGF (fig. $5 \mathrm{a}$ and $\mathrm{b}$ ) and VEGF (fig. $5 \mathrm{c}$ and $\mathrm{d}$ ) but not TGF- $\beta 1$ (data not shown).

\section{RELM- $\beta$ induces phosphorylation of ERK1/2, PI3K and Akt}

RELM- $\beta$ induced transient phosphorylation of ERK1/2, PI3K and Akt in HBECs in a concentration-dependent fashion, which was evident as early as $10 \mathrm{~min}$ after RELM- $\beta$ exposure and reverted towards, but was not completely back to "baseline", within $60 \mathrm{~min}$ (fig. 6).

\section{DISCUSSION}

RELM family members are of increasing interest as mediators of inflammation and remodelling, not only in the respiratory tract but also in blood vessels and the mucosa of the gut. Although RELM- $\beta /$ FIZZ-2 expression has been reported in murine asthma "models" [4, 7], there has been no systematic investigation of its expression in human airways diseases characterised by remodelling, most typically asthma, and its possible effects on human airway epithelial cells.

In this study, using bronchial biopsies from human asthma and primary cultures of human airways epithelial cells, we have generated a body of data supporting the hypothesis that RELM- $\beta$ /FIZZ-2 plays a mechanistic role in airway remodelling

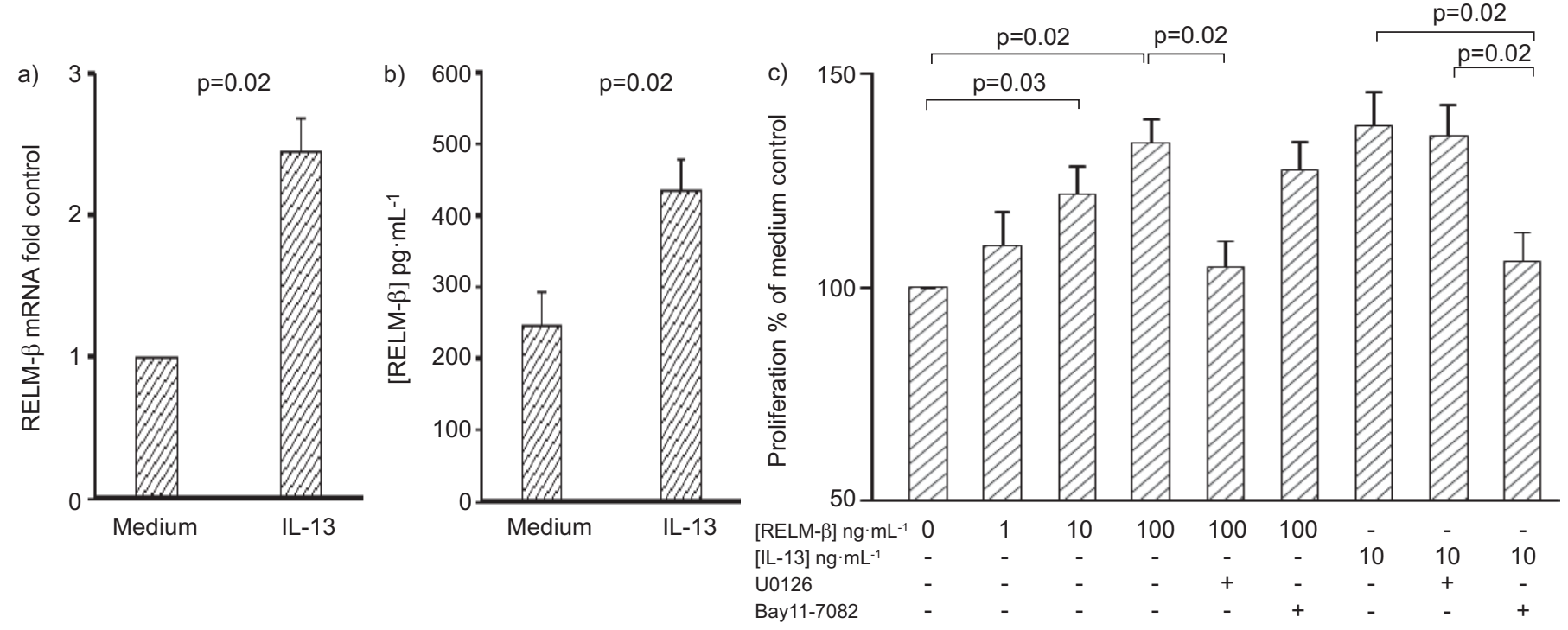

FIGURE 3. Interleukin (IL)-13-induced expression of resistin-like molecule (RELM)- $\beta$, and the effect of RELM- $\beta$ and IL-13 on proliferation of airway epithelial cells. Primary human bronchial epithelial cells (HBECs) were cultured with and without IL-13 (10 ng. $\mathrm{mL}^{-1}$ ) for 24 (quantitative PCR) and 48 (ELISA) h. a) RELM- $\beta$ mRNA and b) RELM- $\beta$ protein present in supernatants. c) RELM- $\beta$ increases proliferation of HBECs concentration dependently, an effect abolished by the extracellular signal-regulated kinase

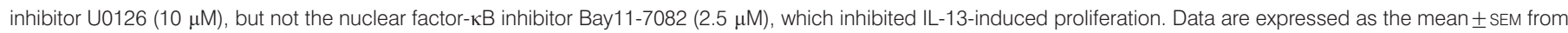
at least four independent experiments. Data were analysed using the t-test. 

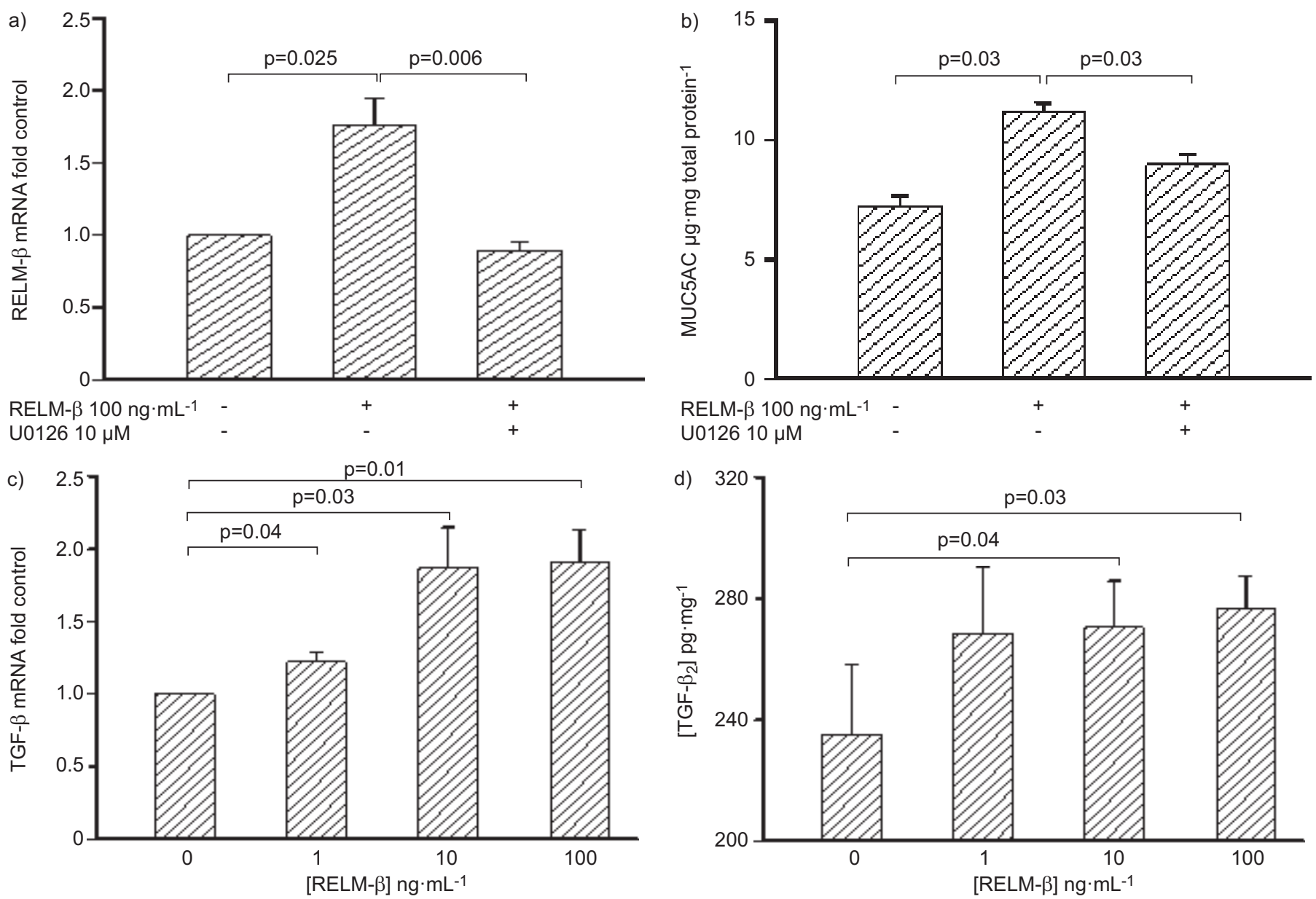

FIGURE 4. Resistin-like molecule (RELM)- $\beta$ increases human bronchial epithelial cell (HBEC) mucin and transforming growth factor (TGF)- $\beta 2$ expression. RELM- $\beta$ (100 ng. $\mathrm{mL}^{-1}$ ) induced U0126-inhibitable mucin (MUC)5AC mRNA and protein expression by HBECs after a) 24 (quantitative PCR) and b) 48 (ELISA) h, respectively. RELM- $\beta$ also increased TGF- $\beta 2$ mRNA and protein expression after c) 24 (quantitative PCR) and d) 48 (ELISA) h. Data are expressed as the mean \pm SEM of four independent experiments and are analysed using the t-test.

in diseases, such as asthma. RELM- $\beta /$ FIZZ-2 was overexpressed in the bronchial mucosa of asthmatics to a degree that correlated with impaired lung function and local epithelial mucin production. Its presence in the lumen of the airways suggests local release. The cytokine IL-13, considered to be an important airway remodelling cytokine in humans, increased the expression of RELM- $\beta$ /FIZZ- 2 by primary airway epithelial cells, a phenomenon also described in animals [7]. This provides one possible mechanistic link between T-helper cell type 2 cytokine expression and RELM- $\beta /$ FIZZ-2 induction. In turn, RELM- $\beta /$ FIZZ-2 increased proliferation of airway epithelial cells and their secretion of TGF- $\beta 2$, EGF and VEGF, all of which are important remodelling mediators. Finally, RELM- $\beta$ induced production of mucin. The fact that epithelial mucin production correlated with RELM- $\beta$ /FIZZ-2 expression suggests that the latter is an important driver, either directly or indirectly, for the former process. The fact that RELM- $\beta$ - and MUC5AC-expressing cells were relatively distinct allows the further hypothesis that they represent functional subgroups of epithelial cells. Excessive sputum production and mucous hyperplasia in the airway mucosa are, of course, cardinal clinical and pathophysiological features of human asthma and other obstructive airways diseases, as well as being important causes of morbidity and mortality [16-18].

Of the 21 different mucin genes identified in human tissues [19], in this study, we chose to measure the expression of MUC5AC because it is one of the major secreted mucins in the airways of asthma patients [20-22]. In addition, MUC5AC is produced within the airways epithelium, while MUC5B expression is restricted to cells of the submucosal glands [23-25]. Although, in animals, direct delivery of RELM- $\beta$ into the airways has been reported to cause mucous hyperplasia [7], there is a lack of direct evidence showing that RELM- $\beta$ acts directly on airway epithelial cells. Our data confirm this for the first time in humans.

Our data are also consistent with the hypothesis that RELM- $\beta$ / FIZZ-2 mediates airway remodelling through induction of an array of remodelling mediators, including TGF- $\beta 2$, EGF and VEGF, in airway epithelial cells. In further support of this hypothesis, elevated TGF- $\beta 2$ (but not TGF- $\beta 1$ ) [26] and EGF expression [27] have been linked with mucin production in asthma. VEGF is also a well-established remodelling mediator in asthma, inducing angiogenesis, among other effects. VEGF 

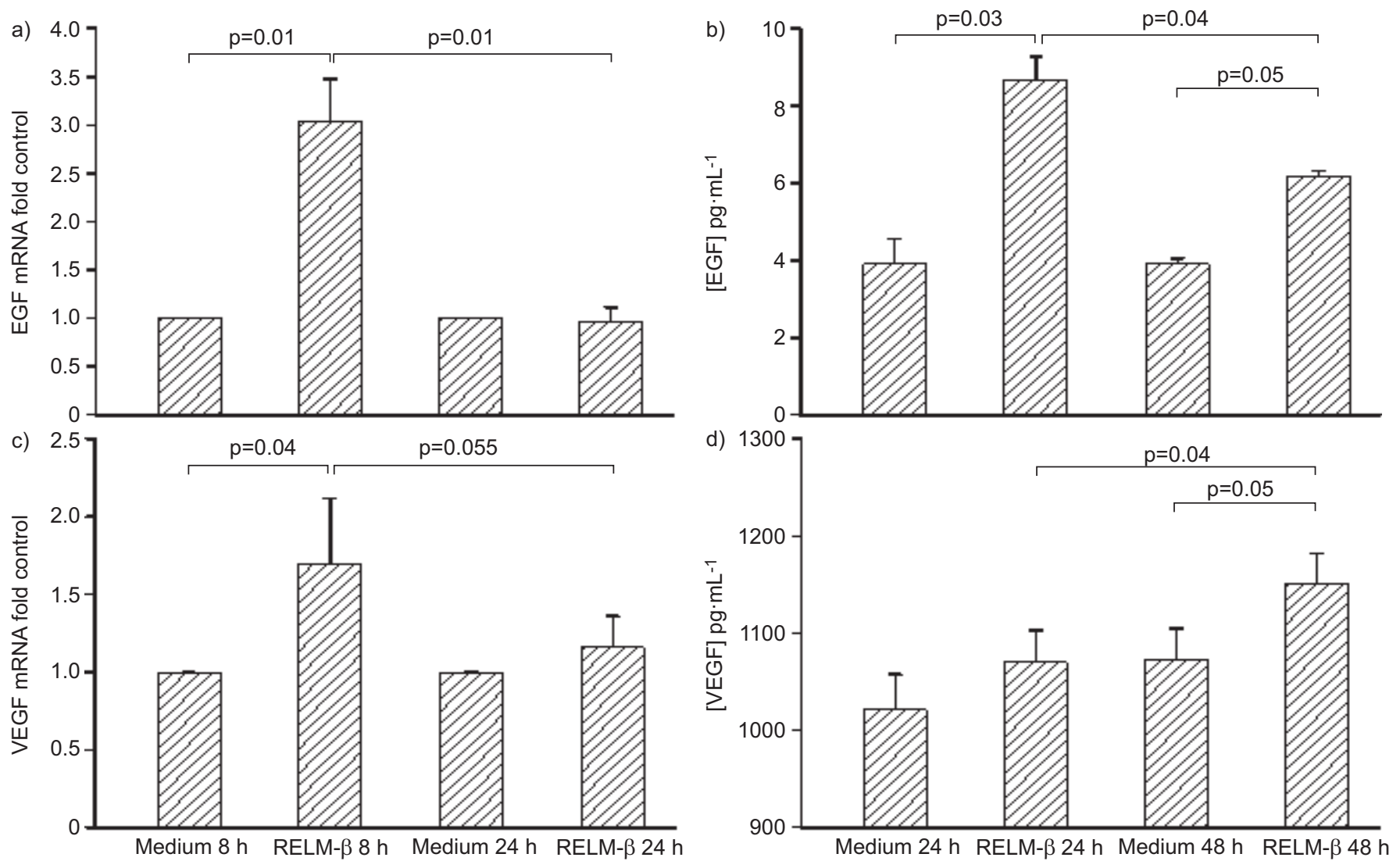

FIGURE 5. Resistin-like molecule (RELM)- $\beta$ increases human bronchial epithelial cell epidermal growth factor (EGF) and vascular endothelial growth factor (VEGF) expression. Cells were cultured with RELM- $\beta\left(10 \mathrm{ng} \cdot \mathrm{mL}^{-1}\right)$ for $\leqslant 48 \mathrm{~h}$. a) and c) EGF and VEGF mRNA measured by qPCR; b) and d) proteins in supernatants measured by ELISA. Data are expressed as the mean \pm SEM of four independent experiments and are analysed using the t-test.

a)
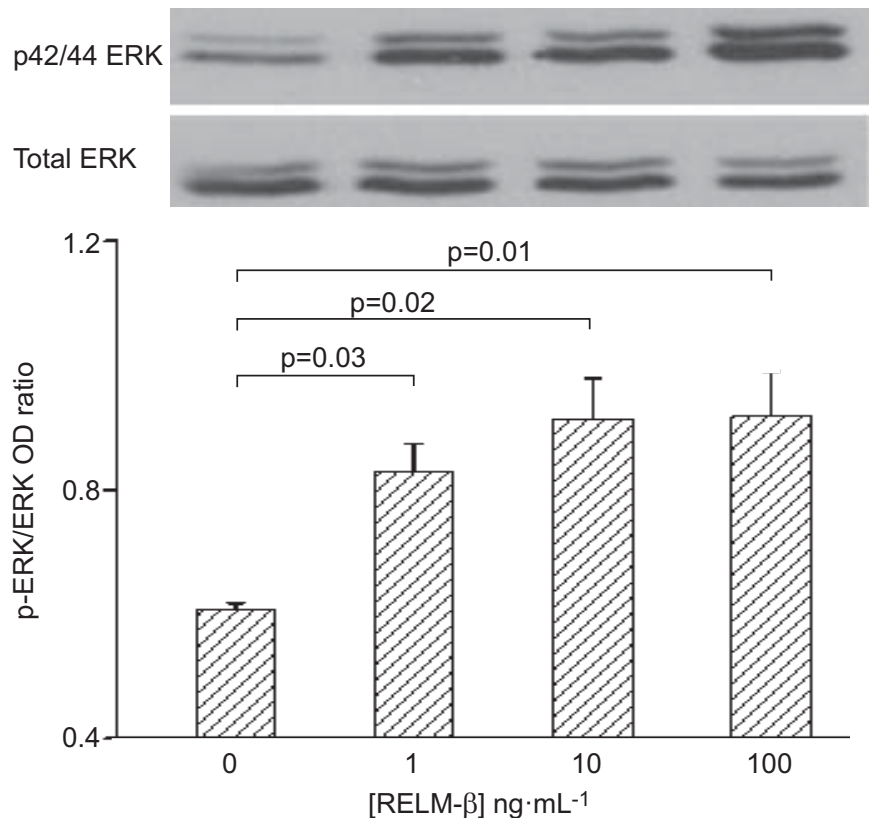

b)

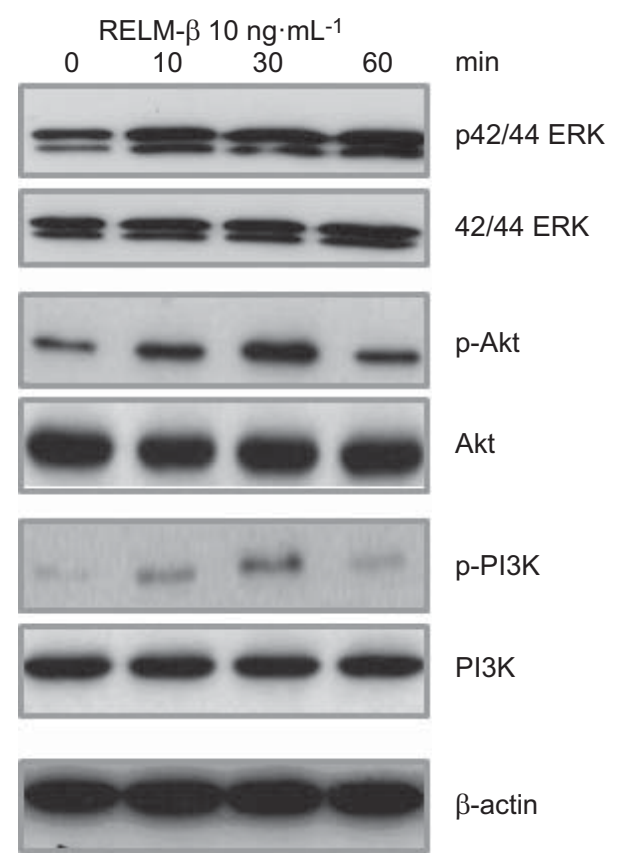

FIGURE 6. Resistin-like molecule (RELM)- $\beta$ induces phosphorylation ( $\mathrm{p}-$ ) of signal-regulated kinase (ERK), phosphatidylinositol 3-kinase (PI3K) and Akt in human primary airways epithelial cells. a) RELM- $\beta$-induced phosphorylation of ERK at $10 \mathrm{~min}$ after stimulation in a concentration-dependent fashion. Data are presented as the mean \pm SEM of four independent experiments and were analysed by t-test. b) Time course of RELM- $\beta$-induced phosphorylation of ERK, PI3K and Akt compared with total proteins and the housekeeping gene $\beta$-actin detected by Western blotting. 
transgenic mice developed an asthma-like phenotype with inflammation, parenchymal and vascular remodelling, oedema, mucous metaplasia, and airway hyperresponsiveness [28]. Taken together, these data suggest the possibility that RELM- $\beta$ /FIZZ-2 induced mucin production in the present study, both directly and indirectly, through induction of TGF- $\beta 2$, EGF and VEGF. This and the effects of RELM- $\beta$ on other cells relevant to airway remodelling are currently being explored in our group.

Finally, our data also suggest that the effects of RELM- $\beta$ on epithelial cells rely largely on ERK, but not NF- $\kappa \mathrm{B}$, signalling, in contradistinction to those of IL-13. In view of a previous report that RELM- $\beta$ /FIZZ-2 acutely and markedly activated ERK expression in primary cultured hepatocytes [29], we sought and found a similar effect of RELM- $\beta /$ FIZZ-2 rapidly and transiently phosphorylating ERK1/2 in human airways epithelial cells. RELM- $\beta$ /FIZZ-2 also activated phosphorylation of PI3K and Akt. Together, these data suggest that ERK and PI3K/Akt signalling play a role in RELM- $\beta /$ FIZZ-2induced proliferation and differentiation of airways epithelial cells, but since the receptor or receptors for RELM- $\beta /$ FIZZ-2 remain to be identified, it cannot yet be determined whether these effects are direct or indirect.

We are currently undertaking further studies to compare RELM- $\beta$ /FIZZ-2 expression with other remodelling changes in the asthmatic bronchial mucosa $e x$ vivo and to investigate its possible production by other structural cells, such as fibroblasts and endothelial cells, as our present data suggest. In this context, a very recent study has suggested that RELM- $\beta$ /FIZZ-2 plays a role in pulmonary fibrosis, possibly through inducing production of type I collagen and smooth muscle- $\alpha$ actin by fibroblasts [30]. Targeting RELM- $\beta /$ FIZZ-2 or its molecular signalling may prove an effective therapeutic strategy to reduce mucus production in asthma and other chronic inflammatory airways diseases where it is produced to excess, a potentially fatal problem for which there is as yet no remedy.

\section{SUPPORT STATEMENT}

This study was supported by the Medical Research Council and Asthma UK. Financial support was also given by the UK Department of Health via a National Institute for Health Research Comprehensive Biomedical Research Centre award to Guy's and St Thomas' NHS Foundation Trust (London, UK) in partnership with King's College London and King's College Hospital NHS Foundation Trust (both London, UK).

\section{STATEMENT OF INTEREST}

None declared.

\section{ACKNOWLEDGEMENTS}

The authors are grateful to K. Jones, C. Reinholtz, H. Bull, K. Williams and L. Siew (Dept of Asthma, Allergy and Respiratory Science, King's College London, London, UK) for their help recruiting patients, collecting endobronchial biopsies and documenting clinical information.

\section{REFERENCES}

1 Steppan CM, Lazar MA. The current biology of resistin. J Intern Med 2004; 255: 439-447.

2 Asano T, Sakosda H, Fuijshiro M, et al. Physiological significance of resistin and resistin-like molecules in the inflammatory process and insulin resistance. Curr Diabetes Rev 2006; 2: 449-454.
3 Steppan CM, Brown EJ, Wright CM, et al. A family of tissue-specific resistin-like molecules. Proc Natl Acad Sci USA 2001; 98: 502-506.

4 Holcomb IN, Kabakoff RC, Chan B, et al. FIZZ1, a novel cysteinerich secreted protein associated with pulmonary inflammation, defines a new gene family. EMBO J 2000; 19: 4046-4055.

5 Teng X, Li D, Champion HC, et al. FIZZ1/RELM $\alpha$, a novel hypoxia-induced mitogenic factor in lung with vasoconstrictive and angiogenic properties. Circ Res 2003; 92: 1065-1067.

6 Yang RZ, Huang Q, Xu A, et al. Comparative studies of resistin expression and phylogenomics in human and mouse. Biochem Biophys Res Commun 2003; 310: 927-935.

7 Mishra A, Wang M, Schlotman J, et al. Resistin-like molecule- $\beta$ is an allergen-induced cytokine with inflammatory and remodeling activity in the murine lung. Am J Physiol Lung Cell Mol Physiol 2007; 293: L305-L313.

8 McVay LD, Keilbaugh SA, Wong TM, et al. Absence of bacterially induced RELM $\beta$ reduces injury in the dextran sodium sulfate model of colitis. J Clin Invest 2006; 116: 2914-2923.

9 Angelini DJ, Su Q, Yamaji-Kegan K, et al. Resistin-like molecule- $\beta$ in scleroderma-associated pulmonary hypertension. Am J Respir Cell Mol Biol 2009; 41: 553-561.

10 Ying S, O'Connor B, Ratoff J, et al. Expression and cellular provenance of thymic stromal lymphopoietin and chemokines in patients with severe asthma and chronic obstructive pulmonary disease. J Immunol 2008; 181: 2790-2798.

11 Ying S, O'Connor B, Ratoff J, et al. Thymic stromal lymphopoietin expression is increased in asthmatic airways and correlates with expression of Th2-attracting chemokines and disease severity. J Immunol 2005; 174: 8183-8190.

12 Steiling K, Kadar AY, Bergerat A, Flanigon J, et al. Comparison of proteomic and transcriptomic profiles in the bronchial airway epithelium of current and never smokers. PLoS One 2009; 4: e5043.

13 Corrigan CJ, Wang W, Meng Q, et al. T-helper cell type 2 (Th2) memory $\mathrm{T}$ cell-protentiating cytokine 25 has the potential to promote angiogenesis in asthma. Proc Natl Acad Sci USA 2011; 108: 1579-1584.

14 Ikari A, Atomi K, Kinjo K, et al. Magnesium deprivation inhibits a MEK-ERK cascade and cell proliferation in renal epithelial MadinDarby canine kidney cells. Life Sci 2010; 86: 766-773.

15 Shao MX, Nadel JA. Neutrophil elastase induces MUC5AC mucin production in human airway epithelial cells via a cascade involving protein kinase $\mathrm{C}$, reactive oxygen species, and TNFalpha-converting enzyme. J Immunol 2005; 175: 4009-4016.

16 Carroll NG, Mutavdzic S, James AL. Increased mast cells and neutrophils in submucosal mucous glands and mucus plugging in patients with asthma. Thorax 2002; 57: 677-682.

17 Fahy JV. Goblet cell and mucin gene abnormalities in asthma. Chest 2002; 122: Suppl. 6, 320S-326S.

18 Ordonez CL, Khashayar R, Wong HH, et al. Mild and moderate asthma is associated with airway goblet cell hyperplasia and abnormalities in mucin gene expression. Am J Respir Crit Care Med 2001; 163: 517-523.

19 Williams OW, Sharafkhaneh A, Kim V, et al. Airway mucus: from production to secretion. Am J Respir Cell Mol Biol 2006; 34: 527-536.

20 Ali MS, Pearson JP. Upper airway mucin gene expression: a review. Laryngoscope 2007; 117: 932-938.

21 Rousseau K, Kirkham S, McKane S, et al. Muc5b and Muc5ac are the major oligomeric mucins in equine airway mucus. Am J Physiol Lung Cell Mol Physiol 2007; 292: L1396-L1404.

22 Kirkham S, Sheehan JK, Knight D, et al. Heterogeneity of airways mucus: variations in the amounts and glycoforms of the major oligomeric mucins MUC5AC and MUC5B. Biochem J 2002; 361: 537-546.

23 Rose MC, Voynow JA. Respiratory tract mucin genes and mucin glycoproteins in health and disease. Physiol Rev 2006; 86: 245-278.

24 Turner J, Jones CE. Regulation of mucin expression in respiratory diseases. Biochem Soc Trans 2009; 37: 877-881. 
25 Sharma P, Dudus L, Nielsen PA, et al. MUC5B and MUC7 are differentially expressed in mucous and serous cells of submucosal glands in human bronchial airways. Am J Respir Cell Mol Biol 1998; 19: 30-37.

26 Chu HW, Balzar S, Seedorf GJ, et al. Transforming growth factor$\beta 2$ induces bronchial epithelial mucin expression in asthma. Am J Pathol 2004; 165: 1097-1106.

27 Burgel PR, Nadel JA. Epidermal growth factor receptor-mediated innate immune responses and their roles in airway diseases. Eur Respir J 2008; 32: 1068-1081.
28 Lee CG, Link H, Baluk P, et al. Vascular endothelial growth factor (VEGF) induces remodeling and enhances TH2-mediated sensitization and inflammation in the lung. Nat Med 2004; 10: 1095-1103.

29 Kushiyama A, Shojima N, Ogihara T, et al. Resistin-like molecule beta activates MAPKs, suppresses insulin signaling in hepatocytes, and induces diabetes, hyperlipidemia, and fatty liver in transgenic mice on a high fat diet. J Biol Chem 2005; 280: 42016-42025.

30 Liu T, Baek HA, Yu H, et al. FIZZ2/RELM- $\beta$ induction and role in pulmonary fibrosis. J Immunol 2011; 187: 450-461. 